Brit. J. vener. Dis. (1959), 35, 84.

\title{
BACTERIOLOGICAL AND BIOCHEMICAL INVESTIGATIONS IN REITER'S SYNDROME*
}

\author{
GEORGE W. CSONKA
}

St. Mary's Hospital, London, W.2

As part of a study of a large consecutive series of cases with Reiter's syndrome (Reynolds and Csonka, 1958; Csonka, 1958), the results of a number of laboratory tests have been brought together in this paper and an attempt is made to assess their value in the diagnosis of this condition.

\section{Clinical Material}

Of 211 cases studied, 98 had urethritis and arthritis, with conjunctivitis or iritis, 109 had urethritis and arthritis only, and four had arthritis, plantar fasciitis, and conjunctivitis without evidence of genital infection. All the laboratory tests were performed at St. Mary's Hospital, Paddington, and at the Wright-Fleming Institute, with the exception of the investigation for pleuropneumonia-like organisms which was conducted by Dr. E. Klieneberger-Nobel at the Lister Institute, and the estimation of C-reactive protein which was made by Dr. J. K. Oates at the London Hospital.

For various reasons some of the tests mentioned later were not performed in every case:

(i) During the early stages of the study, fewer routine tests were carried out in the mild cases than in the more severe ones, and there is therefore a slight bias to overrepresent the more severely affected.

(ii) Several procedures were planned for a limited number of cases, sufficient only to allow an assessment of their potentialities in Reiter's syndrome.

(iii) Some of the tests were not available at the start of the series.

Table I shows the frequency of the principal clinical features. Of the 211 patients, 207 were male and 4 female, 184 were white and 27 coloured, and the mean age was 31 years (range 15-59).

* Received for publication September 22, 1958.
TABLE I

FREQUENCY OF PRINCIPAL CLINICAL FEATURES

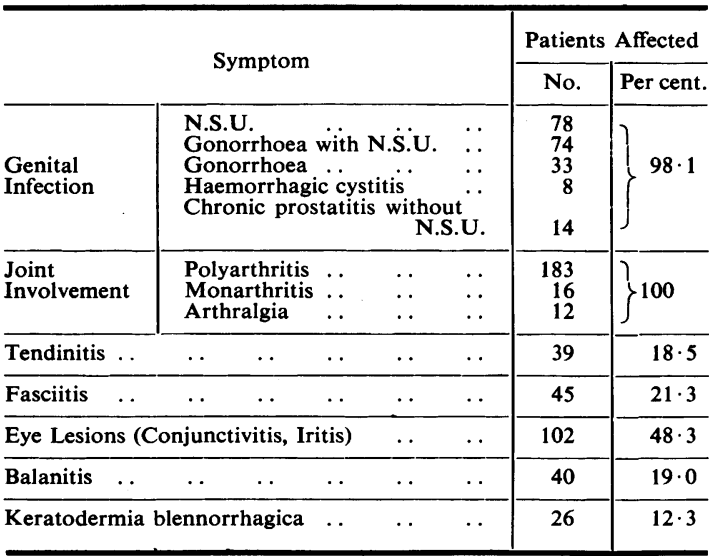

\section{Investigations}

Pleuropneumonia-like Organisms (PPLO). - The results of cultures and complement-fixation test against PPLO are recorded in Table II (opposite). The patients were untreated when the cultures were obtained. The control group consisted of healthy male hospital staff and, as urethral discharges were not present, one had the choice of scraping the urethra or of obtaining urine for the bacteriological investigation. Urine was obviously to be preferred if it could be shown suitable for isolating PPLO. This was in fact found to be the case by Dr. Klieneberger-Nobel (personal communication). 
TABLE II

\begin{tabular}{|c|c|c|c|c|}
\hline \multirow{2}{*}{ Condition } & \multirow{2}{*}{ Culture } & \multirow{2}{*}{$\begin{array}{l}\text { No. } \\
\text { Tested }\end{array}$} & \multicolumn{2}{|c|}{ Positive Cultures } \\
\hline & & & No. & Per cent. \\
\hline $\begin{array}{l}\text { Acute } \\
\text { Reiter's } \\
\text { Syndrome }\end{array}$ & $\begin{array}{l}\text { Urethral secretions } \\
\text { Synovial fluid } \\
\text { Conjunctival } \\
\quad \text { secretions }\end{array}$ & $\begin{array}{r}17 \\
5 \\
2\end{array}$ & $\begin{array}{l}2 \\
-\end{array}$ & $11 \cdot 8$ \\
\hline $\begin{array}{l}\text { Acute } \\
\text { N.S.U. }\end{array}$ & Urethral secretions & 66 & 31 & $46 \cdot 9$ \\
\hline $\begin{array}{l}\text { Healthy } \\
\text { Subjects }\end{array}$ & Urine & 96 & 2 & $2 \cdot 1$ \\
\hline
\end{tabular}

(2) Complement-fixation test (C.F.T.)

\begin{tabular}{|c|c|c|c|c|c|}
\hline \multirow{2}{*}{\multicolumn{3}{|c|}{ Condition }} & \multirow{3}{*}{$\begin{array}{c}\begin{array}{c}\text { No. } \\
\text { Tested }\end{array} \\
31\end{array}$} & \multicolumn{2}{|c|}{ Positive C.F.T. } \\
\hline & & & & \multirow{2}{*}{$\frac{\text { No. }}{2}$} & \multirow{2}{*}{$\frac{\text { Per cent }}{6.4}$} \\
\hline Reiter's Syndrome .. & . & . & & & \\
\hline N.S.U. & $\cdots$ & $\cdots$ & 104 & 19 & $18 \cdot 2$ \\
\hline $\begin{array}{l}\text { Medical In-Patients } \\
\text { (excluding urogenit }\end{array}$ & $\begin{array}{l}\cdots \\
\text { ases) }\end{array}$ & $\cdots$ & 111 & 5 & $4 \cdot 5$ \\
\hline
\end{tabular}

In the group with Reiter's syndrome the proportion of positive cultures and complement-fixation tests was low compared with that in the nonspecific urethritis group, and our findings do not support the view of Dienes and Weinberger (1952) that PPLO may be aetiologically important in Reiter's syndrome.

Gonococcus.-This organism was seen in 107 Gram-stained urethral specimens of 195 cases examined. The gonococcal complement-fixation test was performed in 168 cases (Table III). It was of little practical value in the investigation of our patients, but the use of this test in other departments in cases with arthritis, fasciitis, or uveitis of undiagnosed cause led to a number with a positive test being referred to the V.D. clinic. A few of these were found to suffer from Reiter's syndrome but none from true suppurative gonococcal arthritis.
TABLE III

RESULTS OF GONOCOCCAL COMPLEMENT-FIXATION TEST

\begin{tabular}{ll|c|c|c}
\hline \multicolumn{2}{c|}{$\begin{array}{c}\text { History } \\
\text { of } \\
\text { Gonorrhoea }\end{array}$} & $\begin{array}{c}\text { No. of } \\
\text { Patients } \\
\text { Tested }\end{array}$ & Ponococcal Complement-Fixation Test \\
\hline Present & $\ldots$ & 122 & 59 & Negative \\
Absent & $\cdots$ & 46 & 7 & 63 \\
\hline Total & $\ldots$ & 168 & 66 & 39 \\
\hline
\end{tabular}

Bacteriological Examination of Urine.-Table IV shows the urinary bacteriological and microscopical findings in 44 untreated early cases. This group was selected by excluding patients with proved gonorrhoea and including a high proportion with pronounced urinary symptoms. Blood-agar and MacConkey's media were used, and the results suggest that the urine can be expected to be sterile on these media even in the presence of symptoms of cystitis and pyuria. When urinary organisms are found, a careful search for organic lesions of the lower urogenital tract seems to be indicated.

Prostate.-Prostatic secretions were obtained by massage and examined by dark-field microscopy for pus cells. A diagnosis of prostatitis was made on finding ten or more pus cells per high-power field with evidence of clumping. In the absence of specific features of chronic prostatitis, these arbitrary laboratory criteria are the most universally accepted ones in its diagnosis (Hinman, 1935; Pelouze, 1939; Mason, Murray, Oates, and Young, 1958).

A great number of authors have reported a high incidence of chronic prostatitis in Reiter's syndrome; most recently Mason and others (1958) found 95 per cent. of prostatitis in 59 cases.

In the present series, 55 per cent. of 132 patients tested had prostatitis. In eighteen cases with joint involvement urethritis had apparently never been

TABLE IV

MID-STREAM URINE: CULTURE AND DEPOSIT

\begin{tabular}{|c|c|c|c|c|c|}
\hline \multirow[b]{2}{*}{ Urinary Symptoms } & \multirow[b]{2}{*}{$\begin{array}{l}\text { No. } \\
\text { Tested }\end{array}$} & \multicolumn{4}{|c|}{ Result } \\
\hline & & $\begin{array}{l}\text { No abnormal deposit } \\
\text { or a few pus cells only } \\
\text { Sterile }\end{array}$ & $\underset{\text { Sterile }}{\text { Pus cells }+}+$ & $\begin{array}{c}\text { Red blood cells }+++ \\
\text { Pus cells }+++ \\
\text { Sterile }\end{array}$ & $\begin{array}{c}\text { Pus cells }++ \\
\text { Urinary organisms } \\
\text { (E. coli; B. proteus; } \\
\text { staphylococci; } \\
\text { Strept. faecalis) }\end{array}$ \\
\hline $\begin{array}{l}\text { N.S.U. Only .. } \\
\text { N.S.U., Dysuria, and Frequency of } \\
\text { Micturition.. }\end{array}$ & $\begin{array}{l}17 \\
27\end{array}$ & $\begin{array}{r}11 \\
1\end{array}$ & $\begin{array}{r}5 \\
11\end{array}$ & - & $\begin{array}{l}1 \\
7 t\end{array}$ \\
\hline Total $\ldots$ & 44 & 12 & 16 & 8 & 8 \\
\hline
\end{tabular}

* These cases showed the clinical picture of "haemorrhagic cystitis".

+ Three of the patients had urethral strictures, one had a vesical calculus and another suffered from a neurogenic bladder with chronic retention. 
present, but fourteen of these had marked chronic prostatitis (Table V).

TABLE V

MICROSCOPICAL EXAMINATION OF PROSTATIC SECRETIONS

\begin{tabular}{|c|c|c|c|c|}
\hline \multirow[t]{2}{*}{ Time of Examination } & \multicolumn{2}{|c|}{$\begin{array}{l}10 \text { or more Pus } \\
\text { Cells per High- } \\
\text { power Field }\end{array}$} & \multicolumn{2}{|c|}{ Normal Fluid } \\
\hline & No. & Per cent. & No. & Per cent. \\
\hline $\begin{array}{l}\text { Within } 3 \text { months of Onset } \\
\text { of Reiter's Syndrome }\end{array}$ & 20 & $46 \cdot 5$ & 23 & $53 \cdot 5$ \\
\hline At a Later Stage ... & 53 & $59 \cdot 9$ & 36 & $40 \cdot 1$ \\
\hline 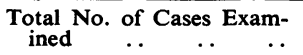 & 73 & $55 \cdot 3$ & 59 & $44 \cdot 7$ \\
\hline
\end{tabular}

Full value cannot be extracted either from the published studies or from our own results owing to the lack of fully adequate control groups for comparison.

Blood Count.-In the experience of some writers, anaemia is both common and marked in Reiter's syndrome (Twiss and Douglas, 1946; StormMathisen, 1946), but others deny its existence in this condition (Beiglböck, 1943; Miller and McIntyre, 1945; Feiring, 1946; Vallee, 1946; Wrigley, 1946). In our series, 88 consecutive patients were tested and fourteen ( 15.9 per cent.) showed a slight to moderate normocytic anaemia which improved spontaneously as the attack came to an end (Table VI). The four-

TABLE VI

RESULTS IN 88 CASES OF REITER'S SYNDROME

HAEMOGLOBIN (Hb)

$(100 \%=14 \cdot 8$ g. per $100 \mathrm{ml}$. $)$

\begin{tabular}{|c|c|c|c|c|c|}
\hline $\begin{array}{l}\text { Hb. } \\
\text { No. }\end{array}$ & $\begin{array}{r}50 \% \\
1\end{array}$ & $\begin{array}{c}-60 \%- \\
2\end{array}$ & $\begin{array}{c}70 \%-80 \\
11\end{array}$ & $\begin{array}{l}\%-90 \\
15\end{array}$ & $\begin{array}{l}0 \%+ \\
59\end{array}$ \\
\hline \multicolumn{6}{|c|}{ WHITE BLOOD COUNT } \\
\hline \multicolumn{2}{|c|}{ Blood Cells } & $\begin{array}{l}\text { Normal } \\
\text { Values }\end{array}$ & & Mean & Range \\
\hline \multicolumn{2}{|c|}{$\begin{array}{l}\text { Total White Blood } \\
\text { Count per c.mm. }\end{array}$} & $4,000-11,000$ & $>11,000$ & \multirow{2}{*}{10,700} & \multirow{2}{*}{$4,500-20,000$} \\
\hline No. of Cases & $\ldots$ & 60 & 28 & & \\
\hline Neutrophils & $\ldots$ & $1,500-7,500$ & $>7,500$ & \multirow{2}{*}{6,400} & \multirow{2}{*}{$1,600-16,400$} \\
\hline No. of Cases & .. & 58 & 30 & & \\
\hline Lymphocytes & $\ldots$ & $1,000-4,500$ & $>4,500$ & \multirow{2}{*}{3,100} & \multirow{2}{*}{$1,000-6,000$} \\
\hline No. of Cases & $\ldots$ & 78 & 10 & & \\
\hline Eosinophils & $\ldots$ & $0-400$ & $>400$ & & \\
\hline No. of Cases & $\ldots$ & 78 & 10 & & \\
\hline Monocytes & . & $0-800$ & $>800$ & & \\
\hline No. of Cases & $\ldots$ & 78 & 10 & & \\
\hline
\end{tabular}

teen patients with anaemia were all judged to have had severe attacks but this association was not invariable, as fifteen of the 74 patients with normal haemoglobin values were severely involved.

As regards the white blood count, the most comprehensive study is that of Paronen (1948), who found a slight leucocytosis of 10,000 to 15,000 white blood cells per c.mm. in 15.8 per cent. of 344 patients, the rest showing normal counts. In our series (Table VI), one-third of the patients tested had a slight to moderate neutrophil leucocytosis. Ten had eosinophilia (450-1,900 eosinophils per c.mm.) but this could be accounted for in five by the presence of intestinal worms.

Erythrocyte Sedimentation Rate.-In common with other observers I found that a raised sedimentation rate was usually associated with active disease, but that a normal rate was a less reliable guide to the clinical state. Of 112 patients with active disease, 25 ( $22 \cdot 3$ per cent.) had a normal sedimentation rate. It was also noted in instances where the main features of the syndrome appeared at different times, that an isloted balanitis or eye lesion, even when severe, was commonly associated with a normal sedimentation rate. When arthritis was present, either alone or with the other symptoms, the sedimentation rate was usually but not invariably raised (Table VII).

TABLE VII

ERYTHROCYTE SEDIMENTATION RATE (Westergren)

\begin{tabular}{|c|c|c|c|}
\hline \multirow{2}{*}{$\begin{array}{l}\text { Presenting Feature } \\
\text { (Reiter's Syndrome) }\end{array}$} & \multirow{2}{*}{$\begin{array}{l}\text { No. } \\
\text { of } \\
\text { Cases }\end{array}$} & \multicolumn{2}{|c|}{$\begin{array}{c}\text { Erythrocyte Sedimentation } \\
\text { Rate }\end{array}$} \\
\hline & & $\underset{(>15 \mathrm{~mm} . / \mathrm{hr})}{\text { Raised }}$ & $\begin{array}{c}\text { Normal } \\
(0-15 \mathrm{~mm} . / \mathrm{hr})\end{array}$ \\
\hline 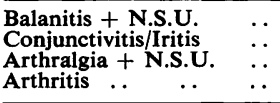 & $\begin{array}{r}4 \\
8 \\
3 \\
97\end{array}$ & $\begin{array}{r}1 \\
1 \\
1 \\
86\end{array}$ & $\begin{array}{r}3 \\
7 \\
2 \\
13\end{array}$ \\
\hline $\begin{array}{l}\text { Convalescent Patients } \\
\text { (Reiter's Syndrome) }\end{array}$ & 25 & 4 & 21 \\
\hline $\begin{array}{l}\text { Uncomplicated N.S.U. } \\
\text { (Controls) }\end{array}$ & 30 & 2 & 28 \\
\hline
\end{tabular}

Electrophoretic Serum Protein Pattern.-This was studied in thirty consecutive patients and has been reported in detail elsewhere (Csonka and Kawerau, 1958). The main changes were a decrease in the albumin fraction and an increase in the alphaglobulins, the gamma-globulin being only slightly raised. A group of healthy medical students and a group of rheumatoid arthritics are included for comparison (Table VIII, opposite). The pattern described, though not specific for Reiter's syndrome, is 
TABLE VIII

ELECTROPHORETIC SERUM PROTEIN FRACTIONS IN REITER'S SYNDROME, RHEUMATOID ARTHRITIS, AND HEALTHY CONTROLS

\begin{tabular}{|c|c|c|c|c|c|c|c|c|c|c|}
\hline \multirow{2}{*}{\multicolumn{3}{|c|}{ Condition }} & \multirow{2}{*}{\multicolumn{2}{|c|}{ No. of Cases }} & \multirow{3}{*}{$\begin{array}{c}\begin{array}{c}\text { Total } \\
\text { Protein } \\
\text { (g./100 ml.) }\end{array} \\
\begin{array}{c}7 \cdot 4 \\
5 \cdot 8-9 \cdot 0\end{array}\end{array}$} & \multirow{3}{*}{$\begin{array}{c}\text { Albumin } \\
\begin{array}{c}48 \cdot 3 \\
33 \cdot 9-62 \cdot 7\end{array}\end{array}$} & \multicolumn{4}{|c|}{$\begin{array}{l}\text { Globulin } \\
\text { (expressed as per cent. of total protein) }\end{array}$} \\
\hline & & & & & & & $\alpha_{1}$ & $\alpha_{2}$ & $\beta$ & $\gamma$ \\
\hline Reiter's Syndrome & . & $\ldots$ & 30 & $\begin{array}{l}\text { Mean value } \\
\quad 2 \text { S.D. }\end{array}$ & & & $2 \cdot 6-12 \cdot 0$ & $5 \cdot 0-19 \cdot 2$ & $\begin{array}{l}13 \cdot 5 \\
7 \cdot 9-19 \cdot 1\end{array}$ & $\begin{array}{c}19 \cdot 0 \\
8 \cdot 4-29 \cdot 6\end{array}$ \\
\hline Rheumatoid Arthritis & $\ldots$ & $\ldots$ & 10 & $\begin{array}{l}\text { Mean value } \\
\pm 2 \text { S.D. }\end{array}$ & $\begin{array}{c}7 \cdot 6 \\
6 \cdot 5-8 \cdot 7\end{array}$ & $\begin{array}{c}41 \cdot 1 \\
33 \cdot 9-48 \cdot 3\end{array}$ & $\begin{array}{c}6 \cdot 4 \\
1 \cdot 8-11 \cdot 0\end{array}$ & $5 \cdot 7-19 \cdot 1$ & $7 \cdot 1-17 \cdot 9$ & $\begin{array}{c}28 \cdot 0 \\
15 \cdot 4-40 \cdot 6\end{array}$ \\
\hline Healthy Controls & $\ldots$ & $\ldots$ & 27 & $\begin{array}{l}\text { Mean value } \\
\pm 2 \text { S.D. }\end{array}$ & $\begin{array}{c}8 \cdot 0 \\
6 \cdot 6-9 \cdot 4\end{array}$ & $\begin{array}{c}63 \cdot 8 \\
52 \cdot 8-74 \cdot 8\end{array}$ & $\begin{array}{c}3 \cdot 8 \\
1 \cdot 2-6 \cdot 4\end{array}$ & $\begin{array}{c}7 \cdot 0 \\
2 \cdot 6-11 \cdot 4\end{array}$ & $\begin{array}{l}10 \cdot 6 \\
6 \cdot 0-15 \cdot 2\end{array}$ & $\begin{array}{c}14 \cdot 8 \\
8 \cdot 1-21 \cdot 5\end{array}$ \\
\hline
\end{tabular}

thought to be sufficiently characteristic to merit further study. Serial tests performed over a period of 8 to 23 months showed that the changes in the protein fractions were correlated with the severity of the syndrome and not with its duration. During convalescence the serum proteins returned to normal.

Differential Agglutination Test (D.A.T.).-The advent of this test has greatly helped to separate classical rheumatoid arthritis, in which about 80 per cent. of cases have a positive test, from similar conditions in which the D.A.T. is usually negative (Brit. med. J., 1956). The test was performed on 23 of our patients with severe Reiter's syndrome and was positive in only two. One of these had "rheumatic nodules" around the elbows; this is rarely seen in Reiter's syndrome and was present in only one other case in the whole series but in this case the D.A.T. was not done.

L.E. Cell Phenomenon.-L.E. cells and the formation of clumps and rosettes were repeatedly looked for in the peripheral blood of fourteen patients with severe active disease. No L.E. cells were found.

C-reactive Protein.-This protein is not normally present in the serum; it is identified by its capacity to form a precipitate with the somatic C-polysaccharide of the pneumococcus, and is commonly found early in bacterial infections, less commonly in viral diseases and in a variety of other conditions. It has been used with some success in assessing the

TABLE IX

C-REACTIVE PROTEIN

\begin{tabular}{c|c|c|c}
\hline \multicolumn{1}{c|}{ Series of Cases } & $\begin{array}{c}\text { No. } \\
\text { of } \\
\text { Cases }\end{array}$ & $\begin{array}{c}\text { Erythrocyte } \\
\text { Sedimentation } \\
\text { Rate Raised } \\
(>15 \mathrm{~mm} . / \mathrm{hr})\end{array}$ & $\begin{array}{c}\text { C-Reactive Protein } \\
\text { Present } \\
\text { (titre 1/16 or more) }\end{array}$ \\
\hline Clinically Active $\ldots$ & 11 & 8 & 4 \\
\hline Convalescent $\quad .$. & 9 & nil & nil \\
\hline
\end{tabular}

activity of rheumatic fever. Table IX gives the results of this test in twenty patients with Reiter's syndrome; it was found to be of little use in estimating disease activity.

Serum Uric Acid.-This was estimated in 26 consecutive cases and found to be within the normal limits ( 2 to $4 \mathrm{mg}$. per $100 \mathrm{ml}$. serum) in 23 . In the remaining three patients it was repeatedly raised $(5.4$ to $6.7 \mathrm{mg}$. per $100 \mathrm{ml}$.). There was no clinical or radiological evidence of gout in these cases and the symptoms did not respond to colchicine.

\section{Discussion}

The tests here reported can be placed into four groups:

(i) Bacteriological and serological tests for pleuropneumonia-like organisms failed to implicate them as an aetiological agent in Reiter's syndrome.

(ii) Gonococci were commonly found in the urethral discharges, yet the following considerations make it unlikely that this is of primary aetiological significance; the syndrome did not differ clinically (Harkness, 1950; Ford, 1953; Csonka, 1958), radiologically (Reynolds and Csonka, 1958; Murray, Oates, and Young, 1958), or biochemically, whether it was preceded by gonococcal or non-gonococcal urethritis or a combination of both. Typical attacks of Reiter's syndrome were seen at different times after gonococcal and non-gonococcal urethritis in the same patient in the present series, and penicillin cleared the gonococcus from the urethra in every instance yet without preventing the subsequent development of Reiter's syndrome or influencing the established condition. The mild polymorphonuclear leucocytosis, slight constitutional symptoms, and lack of clinical or radiological signs of septic arthritis were further evidence against the gonococcus being a direct cause of Reiter's syndrome.

(iii) Tests designed to measure the activity and severity of the illness include the erythrocyte sedimentation rate, blood count, electrophoretic serum 
protein pattern, and C-reactive protein test. Of these, the erythrocyte sedimentation rate and the serum protein fractions were found to be the most consistently useful.

(iv) Differential diagnostic procedures include the differential agglutination test, search for L.E. cells, and serum uric acid estimation. These tests can occasionally give useful information by excluding similar illnesses. The serum protein fractions may be normal in Reiter's syndrome or may give a fairly constant pattern without being specific for this condition. The gonococcal complement-fixation test is considered to be helpful in drawing attention to unsuspected venereal infection and might with advantage be included as a routine test in the investigation of any case of obscure arthritis, uveitis, or conjunctivitis.

\section{Summary}

The results of a number of biochemical and bacteriological tests in a series of cases with Reiter's syndrome are reported and their significance discussed.
This work was carried out under the aegis of the Medical Research Council Working Party on NonSpecific Urethritis, with the aid of a grant from the U.S. Public Health Service. I wish to thank Dr. G. L. M. McElligott for his permission to investigate the cases under his care and for his invaluable help, and Mr. A. J. King, of the London Hospital, for his interest and advice.

REFERENCES
Beiglböck, W. (1943). Dtsch. med. Wschr., 69, 803.

Brit. med. J. (1956). Leading Article, 1, 1157 .

Csonka, G. W. (1958). Brit. med. J., 1, 1088.

- and Kawerau, E. (1958). Ann. rh॰um. Dis., 17, 429.

Dienes, L., and Weinberger, H. J. (1952). In" "Rheumatic Diseases: based on the Proceedings of the Seventh Internat. Congress on Rheumatic Diseases", p. 401. Saunders, Philadelphia.

on Rheumatic Diseases"', p. 401. Saunders,
Feiring, W. (1946). Ann. intern. Med., 25, 498.

Feiring, W. (1946). Ann. intern. Med., 25, 498.
Ford, D. K. (1953). Brit. J. vener. Dis., 29, 123.

Harkness, A. H. (1950). "Non-Gonococcal Urethritis", p. 99. Livingstone, Edinburgh.

Hinman, F. (1935). "The Principles and Practice of Urology". Saunders, Philadelphia.

Klieneberger-Nobel, E. (1958). Personal communication.

Mason, R. M., Murray, R S., Oates, J. K., and Young, A. C. (1958). Brit. med. J., 1, 748.

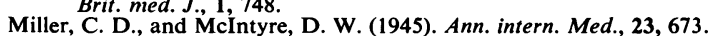

Murray, R. S., Oates, J. K., and Young, A. C. (1958). J. Fac. Radiol., 9, 37.

Paronen, I. (1948). Acta med. scand., Suppl. 212.

Pelouze, P. S. (1939). "Gonorrhea in the Male and Female", 3rd ed., p. 219. Saunders, Philadelphia.

Reynolds, D. F., and Csonka, G. W. (1958). J. Fac. Radiol., 9, 44.

Storm-Mathisen, A. (1946). Acta derm.-venereol. (Stockh.), 26, 547.

Twiss, J. R., and Douglas, A. H. R. (1946). Ann. intern. Med., 24, 1043.

Vallee, B. L. (1946). Arch. intern. Med., 77, 295.

Wrigley, F. (1946). Brit. med. J., 2, 199. 